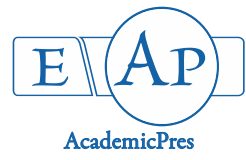

\title{
In vitro Plant Regeneration from Mature Seed Explants of Withania somnifera (L.) Dunal, an Important, Rare and Endangered Medicinal Plant
}

\section{Sape Subba TATA*, Geddam JYOTHIRMAYEE, Owk Aniel KUMAR}

Andhra University, Department of Botany,Visakhapatnam,India; s_tata_s@yahoo.co.in (*corresponding author)

\begin{abstract}
Withania somnifera (L.) Dunal a member of the Solanaceae family, is a traditional medicinal plant commonly known in India as Ashwagandha. It is used for different diseases such as hiccup, cough, rheumatism, tuberculosis, and exhibits excellent antitumor and anti-bacterial activities as well. Direct organogenesis of plants using mature seeds provides faster response and is also a time saving approach, thus the present study was conducted to investigate the optimal concentrations and combinations of plant growth regulators with MS medium for the establishment of an efficient regeneration system in $W$. somnifera using mature seed as an explant. Therefore, an efficient in vitro protocol for high frequency regeneration has been developed using mature seeds as explant. In the present study, the multiple shoots along with embryogenic callus induction was best seen in MS medium supplemented with BAP $(1.5 \mathrm{mg} / \mathrm{L})$ and IAA $(0.5 \mathrm{mg} / \mathrm{L})$. Furthermore, MS medium fortified with GA $3(0.3 \mathrm{mg} / \mathrm{L})$ and IBA $(3.0 \mathrm{mg} / \mathrm{L})$ alone was suited for shoot elongation and rhizogenesis respectively. The rooted plantlets were hardened and successfully established in the soil. The establishment of a highly reproducible regeneration system would greatly influence the efforts of improvement of the hereby studied medicinal plant species through useful gene transfer technology.
\end{abstract}

Keywords: BAP; GA 3 ; IAA; IBA; mature seed; Medharasayana

\section{Introduction}

Withania somnifera (L.) Dunal commonly known as Indian ginseng is a member of the family Solanaceae. It plays an important role in the indigenous medicine of India and is also used as an energy-enhancing tonic known as Medharasayana (Nadkarni, 1976; Williamson, 2002). The medicinal value of this plant is high, especially to treat hiccup, cough, rheumatism, dropsy, inflammations, tuberculosis and exhibits excellent antitumor and antibacterial activities (Kiritikar and Basu, 1975; Devi and Sharada, 1992; Devi, 1996). The conventional method of propagation of this plant is through seeds, but the seed viability is very poor and low germination limits its multiplication.

Raising the demand for wild source, herbal drugs has abetted over the exploitation of medicinal plants, leading to cumulative and sustainable use of forest wealth.

Clonal propagation through tissue cultures offers an alternative to vegetative practices used in the past and has the potential to provide high multiplication of uniform genotypes, resulting in short term gains (Gupta et al., 1993), while selection of explant is one of the important steps for successful in vitro regeneration studies especially for recalcitrant plants. Direct organogenesis of plants using mature seed provides faster response and is also a time saving approach (Aasim et al., 2011).

However, there are few reports in the past that demonstrated the in vitro plant regeneration with mature seeds as an explant in the plant species like spinach (AlKhayri et al., 1992), chickpea (Polisetty et al., 1997), peanut (Pacheco et al., 2007) and Phelloderndron amarense (Yang et al., 2011). Very few reports are available in regard with in vitro plant regeneration system of Withania somnifera using mature seeds and have been published (Sen and Sharma, 1991; Supe et al., 2006; Sharma et al., 2015).

Though some micropropagation studies have been conducted so far, the present paper deals with the development of an efficient plant regeneration using mature seeds of this rare and endangered medicinal plant, Withania somnifera. Further, the establishment of a highly reproducible regeneration system would greatly influence the efforts of improvement of the medicinal plant species through useful gene transfer technology. 
388

\section{Materials and Methods}

The mature seeds of Withania somnifera (L.) Dunal were collected during sunny days and were used as explants. The collected mature seeds were initially washed with tap water, followed by Tween 20 solution. After that, the seeds were surface sterilized by dipping them in $70 \%$ alcohol for about 40 seconds, followed by treatment with $0.3 \% \mathrm{HgCl}_{2}$ for 3 minutes and then washed several times with sterile double distilled water and inoculated onto the culture medium. All the operations were done aseptically under a laminar air flow cabinet.

MS (Murashige and Skoog, 1962) media was used for the current study. The sucrose content of the media was 3\% $(\mathrm{W} / \mathrm{V})$ and the $\mathrm{pH}$ of the media was adjusted at 5.8 before autoclaving at $121^{\circ} \mathrm{C}$ temperature and 15 pound pressure for 15 minutes. Gelling of the media was done with $0.8 \%$ agar agar.

The cultures were maintained under cool fluorescent light intensity of 200-300 lux for 16-8 h light-dark period and the temperature of $22 \pm 2{ }^{\circ} \mathrm{C}$. The effect of cytokinin (6-benzylaminopurine (BAP)) in combination with auxin (indole-3-acetic acid (IAA)), GA 3 (gibberellic acid) and IBA (indole 3 butyric acid) alone with MS medium were observed on propagation, shoot elongation and rooting responses after 2 and 4 weeks respectively.

After root development, the seedlings were transferred into a beaker containing sterilized soil and covered with polyethylene bag, where it was kept in the mist chamber for 15 to 20 days for hardening. Then the seedlings were transferred into pots containing sterilized soil and watered regularly.

\section{Results and Discussion}

The present study was conducted to investigate the optimal concentrations and combinations of plant growth regulators with MS medium for the establishment of an efficient regeneration system in Withania somnifera using mature seeds as an explant.

The supplementation of the MS media with different concentrations of cytokinin (BAP) and auxin (IAA) showed effective multiplication of shoots from the mature seeds. MS medium combination with various concentrations of BAP $(05-3.0 \mathrm{mg} / \mathrm{L})$ with IAA $(0.5 \mathrm{mg} / \mathrm{L}$ and $1.0 \mathrm{mg} / \mathrm{L}$ ) tested for multiple shoot induction in mature seed explants (Table 1). Embryogenic callus with multiple shoots were initiated directly from the seeds after four weeks of culture on all combinations of MS media with BAP and IAA. While, the mature seeds on MS medium without any phytohormones were shrivelled and produced a single shoot, without forming the callus and multiple shoots even after four weeks of culture. The obtained findings suggest that the endogenous levels of phytohormones present in the seeds are not sufficient to sustain their growth and proliferation in the basal MS medium.

In the present study, it was reported that the simultaneous maximum induction of embryogenic callus and multiple shoots took place at high concentration of
BAP with low concentrations of IAA. Similar findings were also observed by a few researchers (Joshi and Kothari, 2007; Rahman et al., 2008; Ashrafuzzaman et al., 2009; Otroshy et al., 2011). The synergistic effect of cytokinin (BAP) and an auxin (IAA) has been demonstrated in many medicinal plants, for example Santolina canescens (Casado et al., 2002), Bupleurum fruticosum (Fraternale et al., 2002) and turmeric (Salvi et al., 2002). One observation of these researchers was that low concentrations of an auxin in combination with a cytokinin, positively modified the frequency of shoot induction and growth. An increased concentration of auxins facilitated more callus formation. BAP at higher concentrations not only reduced the number of shoots, but also resulted in stunted growth of the shoots.

Maximum response resulted when the seeds were cultured on MS medium supplemented with BAP (1.5 $\mathrm{mg} / \mathrm{L})$ and IAA $(0.5 \mathrm{mg} / \mathrm{L})$, with the highest mean number of shoots ( $52.0 \pm 0.22$ per seed) along with extensive yield of callus (Figs. 1a and 1b). Hence, this was opted as the most suitable medium for mass propagation of Withania somnifera through seeds when compared to the previous reports of Sen and Sharma (1991), Supe et al. (2006) and Sharma et al. (2015).

The shoots of $1.0-1.5 \mathrm{~cm}$ in length were excised from the multiple shoot cluster and transferred individually to culture tubes containing MS media with various levels of 0.1-0.5 mg/L GA $\mathrm{GA}_{3}$ for shoot elongation (Table 2). Elongation of shoots was higher, i.e., $(15.6 \pm 0.23 \mathrm{~cm}$ per shoot) on MS medium containing $\mathrm{GA}_{3}(0.3 \mathrm{mg} / \mathrm{L})$ (Fig. 1c). This may be due to the action of $\mathrm{GA}_{3}$ on cell elongation (Qin et al., 2005). The elongated shoots were then implanted on $1 / 2 \mathrm{MS}$ medium containing $3 \%$ (W/V) sucrose with various concentrations of IBA $(1.0-4.0 \mathrm{mg} / \mathrm{L})$ for rhizogenesis (Table 3 ). The medium without IBA did not show any root induction. In contrast, root induction was observed when regenerated shoots were cultured on medium with low concentrations of auxins, whereas at higher concentrations shoots formed callus at the cut end of the stem. These results are in agreement with earlier investigations published (Rout et al., 1999). The optimum rooting frequency $(100 \%)$, root number $(22.2 \pm 0.08$ per shoot) and root length $(15.0 \pm 0.12 \mathrm{~cm}$ per shoot $)$ was obtained on MS medium supplemented with IBA (0.3 $\mathrm{mg} / \mathrm{L})$ (Fig. 1d). Similar findings had also been reported by Chandran et al. (2007) and Rani et al. (2014).

Acclimatized plantlets were transferred to the field with a $95 \%$ survival rate, which was an improvement over $64.9 \%$ survival rate obtained by Sharma et al. (2015). There were no observable differences between the parent plant and in vitro raised plants.

\section{Conclusions}

The protocol developed in the present study appears to be a promising method of propagation of the valuable, endangered medicinal plant Withania somnifera through seeds. It will also be of use in conservation and genetic transformation studies aimed at improving the species. 
Table 1. Evaluation of media for callus formation and multiple shoots proliferation from mature seed explants of Withania somnifera (L.) Dunal

\begin{tabular}{|c|c|c|c|}
\hline \multirow[b]{2}{*}{ S. No. } & \multirow[b]{2}{*}{ Media } & \multicolumn{2}{|c|}{ In vitro response } \\
\hline & & $\begin{array}{l}\text { Intensity of callus } \\
\text { forming }\end{array}$ & Shoot no./Seed \\
\hline 1. & MS basal & - & $1.0 \pm 0.00$ \\
\hline 2. & $\mathrm{MS}+\mathrm{BAP}(0.5 \mathrm{mg} / \mathrm{L})+\mathrm{IAA}(0.5 \mathrm{mg} / \mathrm{L})$ & +++ & $12.0 \pm 0.10$ \\
\hline 3. & $\mathrm{MS}+\mathrm{BAP}(1.0 \mathrm{mg} / \mathrm{L})+\mathrm{IAA}(0.5 \mathrm{mg} / \mathrm{L})$ & +++ & $29.7 \pm 0.18$ \\
\hline 4. & $\mathrm{MS}+\mathrm{BAP}(1.5 \mathrm{mg} / \mathrm{L})+\mathrm{IAA}(0.5 \mathrm{mg} / \mathrm{L})$ & ++++ & $52.0 \pm 0.22$ \\
\hline 5. & $\mathrm{MS}+\mathrm{BAP}(2.0 \mathrm{mg} / \mathrm{L})+\mathrm{IAA}(0.5 \mathrm{mg} / \mathrm{L})$ & ++ & $26.4 \pm 0.25$ \\
\hline 6. & $\mathrm{MS}+\mathrm{BAP}(2.5 \mathrm{mg} / \mathrm{L})+\mathrm{IAA}(0.5 \mathrm{mg} / \mathrm{L})$ & + & $18.6 \pm 0.18$ \\
\hline 7. & $\mathrm{MS}+\mathrm{BAP}(3.0 \mathrm{mg} / \mathrm{L})+\mathrm{IAA}(0.5 \mathrm{mg} / \mathrm{L})$ & + & $14.5 \pm 0.15$ \\
\hline 8. & $\mathrm{MS}+\mathrm{BAP}(0.5 \mathrm{mg} / \mathrm{L})+\mathrm{IAA}(1.0 \mathrm{mg} / \mathrm{L})$ & +++ & $8.0 \pm 0.20$ \\
\hline 9. & $\mathrm{MS}+\mathrm{BAP}(1.0 \mathrm{mg} / \mathrm{L})+\mathrm{IAA}(1.0 \mathrm{mg} / \mathrm{L})$ & +++ & $10.1 \pm 0.28$ \\
\hline 10. & $\mathrm{MS}+\mathrm{BAP}(1.5 \mathrm{mg} / \mathrm{L})+\mathrm{IAA}(1.0 \mathrm{mg} / \mathrm{L})$ & +++ & $20.3 \pm 0.23$ \\
\hline 11. & $\mathrm{MS}+\mathrm{BAP}(2.0 \mathrm{mg} / \mathrm{L})+\mathrm{IAA}(1.0 \mathrm{mg} / \mathrm{L})$ & ++ & $28.1 \pm 0.20$ \\
\hline 12. & $\mathrm{MS}+\mathrm{BAP}(2.5 \mathrm{mg} / \mathrm{L})+\mathrm{IAA}(1.0 \mathrm{mg} / \mathrm{L})$ & + & $15.2 \pm 0.17$ \\
\hline 13. & $\mathrm{MS}+\mathrm{BAP}(3.0 \mathrm{mg} / \mathrm{L})+\mathrm{IAA}(1.0 \mathrm{mg} / \mathrm{L})$ & + & $11.2 \pm 0.08$ \\
\hline
\end{tabular}

- : not observed; + : low; ++ : medium; +++ : moderate; ++++ : high;

values are mean $\pm S E$ of fifty replicates

Table 2. Effect of plant growth regulator $\mathrm{GA}_{3}$ on in vitro shoot elongation of Withania somnifera (L.) Dunal

\begin{tabular}{ccc}
\hline S. No. & Media & Shoot length $(\mathrm{cm})$ \\
\hline 1. & $\mathrm{MS}$ basal & $5.0 \pm 0.00$ \\
2. & $\mathrm{MS}+\mathrm{GA}_{3}(0.10 \mathrm{mg} / \mathrm{L})$ & $9.2 \pm 0.08$ \\
3. & $\mathrm{MS}+\mathrm{GA}_{3}(0.20 \mathrm{mg} / \mathrm{L})$ & $12.0 \pm 0.18$ \\
4. & $\mathrm{MS}+\mathrm{GA}_{3}(0.30 \mathrm{mg} / \mathrm{L})$ & $15.6 \pm 0.23$ \\
5. & $\mathrm{MS}+\mathrm{GA}_{3}(0.40 \mathrm{mg} / \mathrm{L})$ & $12.4 \pm 0.19$ \\
6. & $\mathrm{MS}+\mathrm{GA}_{3}(0.50 \mathrm{mg} / \mathrm{L})$ & $8.3 \pm 0.15$ \\
\hline
\end{tabular}

values are mean \pm SE of ten replicates

Table 3. Effect of growth regulator IBA on in vitro rooting of Withania somnifera (L.) Dunal

\begin{tabular}{ccccc}
\hline \multirow{2}{*}{ S. No. } & Media & \multicolumn{3}{c}{ Rhizogenesis } \\
\cline { 3 - 5 } & & Root induction $(\%)$ & Root no. / shoot & Root length $(\mathrm{cm})$ \\
\hline 01. & MS basal & $00.0 \pm 0.00$ & $00.0 \pm 0.00$ & $0.0 \pm 0.00$ \\
02. & MS + IBA $(1.0 \mathrm{mg} / \mathrm{L})$ & $70.0 \pm 0.18$ & $12.8 \pm 0.12$ & $6.8 \pm 0.04$ \\
03. & MS + IBA $(1.0 \mathrm{mg} / \mathrm{L})$ & $82.0 \pm 0.21$ & $14.4 \pm 0.10$ & $11.8 \pm 0.11$ \\
04. & MS + IBA $(2.0 \mathrm{mg} / \mathrm{L})$ & $94.0 \pm 0.11$ & $18.0 \pm 0.22$ & $10.4 \pm 0.08$ \\
05. & MS + IBA $(3.0 \mathrm{mg} / \mathrm{L})$ & $100.0 \pm 0.00$ & $22.2 \pm 0.08$ & $15.0 \pm 0.12$ \\
06. & MS + IBA $(4.0 \mathrm{mg} / \mathrm{L})$ & $72.0 \pm 0.21$ & $16.0 \pm 0.22$ & $10.4 \pm 0.08$ \\
\hline
\end{tabular}

values are mean $\pm \mathrm{SE}$ of ten replicates 


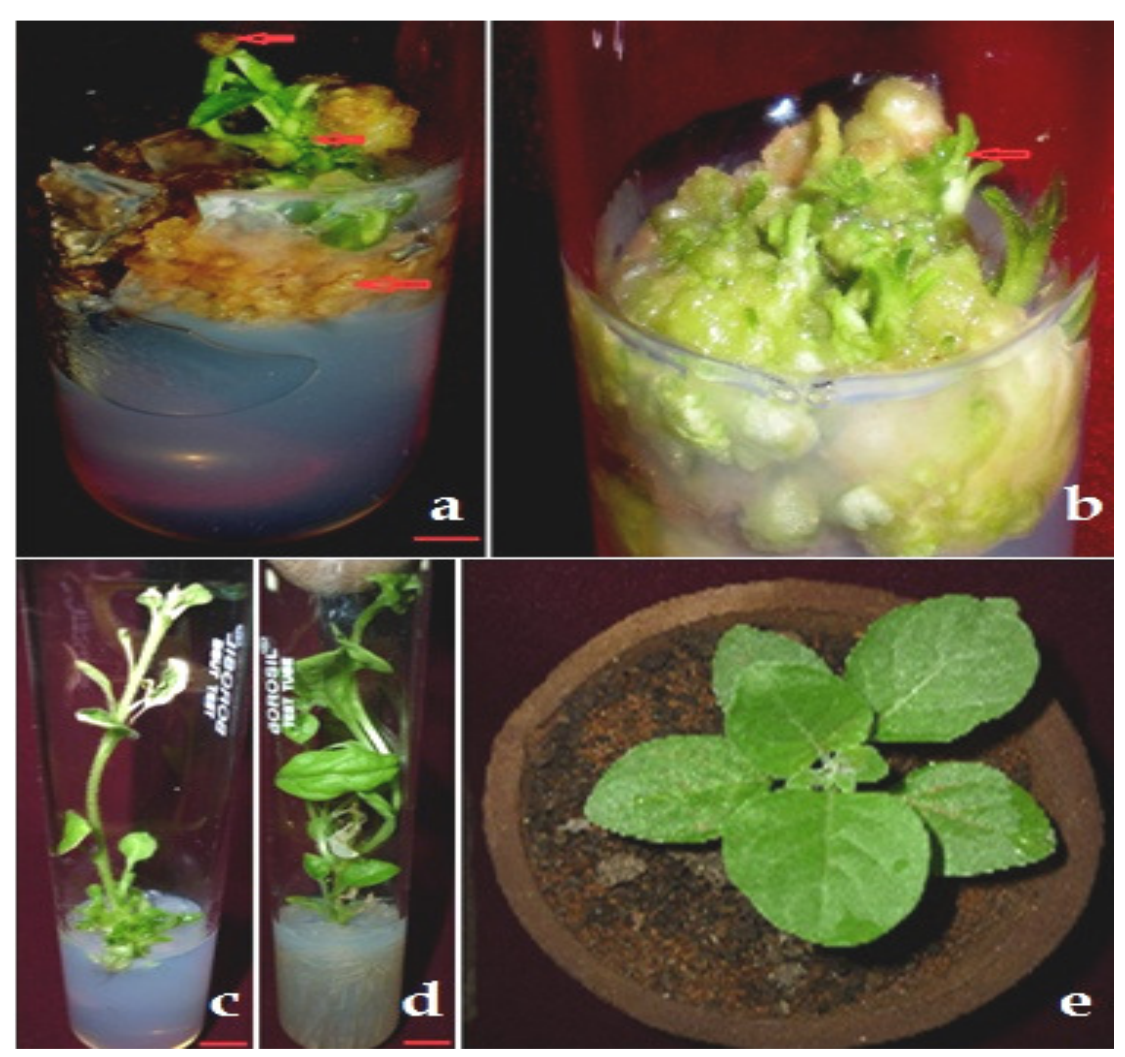

Fig. 1. In vitro plant regeneration from mature seed explants of Withania somnifera (L.) Dunal; a) multiple shoots and embryogenic callus developed from seed explant (arrows show multiple shoots, embryogenic callus and seed coat); b) Emergence of multiple shoots (arrow) from the embryogenic callus; c) Elongated shoot; d) well developed roots consisting plant; e) acclimatized plant. Scale bar length is $0.5 \mathrm{~cm}$

\section{Acknowledgements}

The authors OAK and SST are grateful to UGC-SAPCAS-I, Department of Botany, Andhra University for providing financial assistance.

\section{Conflict of Interest}

The authors declare that there are no conflicts of interest related to this article.

\section{References}

Aasim M, Sahin-Demirbag N, Khawar KM, Kendir H, Ozcan S (2011). Direct axillary shoot regeneration from the mature seed explant of the hairy vetch (Vicia villosa Roth). Archives of Biological Sciences 63:757762.

Al-Khayri JM, Huang FH, Morelock TE, Busharar TA (1992). In vitro plant regeneration of spinach from mature seed-derived callus. In VitroPlant 28(2):64-66

Ashrafuzzaman M, Hossain M, Razi IM, Shahidul M, Haque M, Shahidullah SM, Shahin UZ (2009). Regeneration potential of seedling explants of chilli (Capsicum annuum). African Journal of Biotechnology 8:591-596.

Casado JP, Navarro MC, Utrilla MP, Martinez A, Jiménez J (2002). Micropropagation of Santolina canescens Lagasca and in vitro volatiles production by shoot explants. Plant Cell, Tissue and Organ Culture 69:147-153.

Chandran C, Karthikeyan K, Kulothungan S (2007). In vitro propagation of Withania somnifera (L.) Dunal. from shoot tip and nodal explants. Journal of Scientific Transactions in Environment and Technovation 1(1):15-18.

Devi PU, Sharada AC (1992). In vivo growth inhibitory effect of Withania somnifera (Ashwaganda) on a transplantable mouse tumour, Sarcoma 180. Indian Journal of Experimental Biology 30(3):169-172.

Devi PU (1996). Withania somnifera Dunal (Ashwaganda): potential plant source of a promising drug for cancer chemotherapy and radiosensitization. Indian Journal of Experimental Biology 34(10):927932.

Fraternale D, Giamperi L, Ricci D, Rocchi MBL (2002). Micropropagation of Bupleurum fruticosum: the effect of triacontanol. Plant Cell, Tissue and Organ Culture 69:135-140. 
Gupta PK, Pullman G, Timmis R, Kreitinger M, Carlson WC, Grob J, Wetty E (1993). Forestry in the 21st century: the biotechnology of somaticembryogenesis. Biotechnology 11(4):454 459.

Joshi A, Kothari SL (2007). High copper levels in the medium improves shoot bud differentiation and elongation from the cultured cotyledons of Capsicum annuum L. Plant Cell, Tissue and Organ Culture 88:127133.

Kiritikar KR, Basu BD (1975). Indian medicinal plants. Vol. 3. Bishen Singh Mahendra Pal Singh, Dehra Dun pp 1774-1777.

Murashige T, Skoog K (1962). A revised medium for rapid growth and bioassay with tobacco tissue cultures. Physiologia Plantarum 15(3):473497.

Nadkarni AK (1976). Indian materia medica. Vol. 1. Popular Prakashan Pvt. Ltd. Bombay, Maharashtra, India pp 203-205.

Otroshy M, Moradi K, Nekouei MK, Struik PC (2011). Micropropagation of pepper (Capsicum annuum $\mathrm{L}$.) through in vitro direct organogenesis. Asian Journal of Biotechnology 3:38-45.

Pacheco G, Gagiardi R, Carneiro L, Callado C, Valls J, Mansur E (2007). The role of BAP in somatic embryogenesis induction from seed explants of Arachis species from sections Erectoides and Procumbentes. Plant Cell, Tissue and Organ Culture 88:121-126.

Polisetty R, Paul V, Deveshwar JJ, Khetarpal S, Suresh K, Chandra R (1997). Multiple shoot induction by benzyladenine and complete plant regeneration from seed explants of chickpea (Cicer arietinum L.). Plant Cell Reports 16(8):565-571.

Qin C, DongZ, Liu W, DengZ, TangL (2005). Effects of exogenous plant growth regulator on in vitro regeneration of cotyledon explants in pepper. Notulae Botanicae Horti Agrobotanici Cluj-Napoca 33:25-32.
Rahman MT, Hossain MJ, Khalekuzzaman M (2008). In vitro indirect plantlet regeneration from hypocotyl segments and cotyledonary explant derived calli in lady's finger (Abelmoschus esculentus Monech). Journal of Bio-Science 16:49-57.

Rani A, Kumar M, Kumar S (2014). In vitro propagation of Withania somnifera (L.) Dunal. from shoot apex explants. Journal of Applied and Natural Science 6(1):159-163.

Rout GR, Saxena C, Samantaray S, Das P (1999). Rapid plant regeneration from callus cultures of Plumbago zeylanica. Plant Cell, Tissue and Organ Culture 56:47-51.

Salvi ND, George L, Eapen S (2002). Micropropagation and field evaluation of micropropagated plants of turmeric. Plant Cell, Tissue and Organ Culture 68:143-151.

Sen J, Sharma AK (1991). Micropropagation of Withania somnifera from germinating seeds and shoot tips. Plant Cell, Tissue and Organ Culture 26:71-74.

Sharma N, PriyaS, Manjul D, Eapen PK (2015). Comparative evaluation of in vitro regeneration potential of seeds of $W$. somnifera and $W$. coagulans. Biotechnology International 8(1):21-33.

Supe U, Dhote F, Roymon MG (2006). In vitro plant regeneration of Withania somnifera. Plant Tissue Culture and Biotechnology 16(2):111-115.

Williamson EM (2002). Major herbs of Ayurveda. Churchill Livingstone, London, UKpp 322-323.

YangJL, Zhou CG, Zhao B, Jin CL, Zhang T, Li CH (2011). Rapid direct adventitious shoot organogenesis and plant regeneration from mature seed explants of Phellodendron amurense Rupr. Journal of Medicinal Plants Research 5(18):4560-4565. 